\title{
Paleostress reconstruction of faults recorded in the Niedźwiedzia Cave (Sudetes): insights into Alpine intraplate tectonic of NE Bohemian Massif
}

\author{
Artur Sobczyk $^{1}$ (D) Jacek Szczygieł ${ }^{2}$ (D)
}

Received: 28 December 2019 / Accepted: 16 January 2021 / Published online: 18 February 2021

(c) The Author(s) 2021

\begin{abstract}
Brittle structures identified within the largest karstic cave of the Sudetes (the Niedźwiedzia Cave) were studied to reconstruct the paleostress driving post-Variscan tectonic activity in the NE Bohemian Massif. Individual fault population datasets, including local strike and dip of fault planes, striations, and Riedel shear, enabled us to discuss the orientation of the principal stresses tensor. The (meso) fault-slip data analysis performed both with Dihedra and an inverse method revealed two possible main opposing compressional regimes: (1) NE-SW compression with the formation of strike-slip (transpressional) faults and (2) WNW-ESE horizontal compression related to fault-block tectonics. The (older) NE-SW compression was most probably associated with the Late Cretaceous-Paleogene pan-regional basin inversion throughout Central Europe, as a reaction to ongoing African-Iberian-European convergence. Second WNW-ESE compression was active as of the Middle Miocene, at the latest, and might represent the Neogene-Quaternary tectonic regime of the NE Bohemian Massif. Exposed fault plane surfaces in a dissolution-collapse marble cave system provided insights into the Meso-Cenozoic tectonic history of the Earth's uppermost crust in Central Europe, and were also identified as important guiding structures controlling the origin of the Niedźwiedzia Cave and the evolution of subsequent karstic conduits during the Late Cenozoic.
\end{abstract}

Keywords European Variscides · Paleostress · Tectonic activity $\cdot$ Faults $\cdot$ Caves

\section{Introduction}

Fault planes provide important geological indicators of former stresses recorded in the Earth's upper crust, which are used to infer distinct episodes of regional tectonic regimes (Angélier et al. 1982). Given the limited number of outcrops containing suitable structural indicators, quarries and underground voids typically yield essential insights into structural evolution. Among them, karst caves represent a particular type of natural underground cavity that, under favorable conditions, offers unique exposures of tectonic features (e.g.,

Artur Sobczyk

artur.sobczyk@uwr.edu.pl

Jacek Szczygieł

jacek.szczygiel@us.edu.pl

1 Institute of Geological Sciences, University of Wroclaw, Pl. M. Borna 9, 50-204 Wrocław, Poland

2 Institute of Earth Sciences, University of Silesia, Będzińska 60, 41-200 Sosnowiec, Poland
Szczygieł et al. 2015, 2018). Specifically, the structures that govern cave morphology provide data that is usually impossible to obtain via classical geologic mapping. Worldwide karst systems, large and small, have revealed important tectonic insights, as exemplified in the cases of young (alpine) orogens such as the Tatra Mts (Szczygieł 2015a), old Variscan massifs such as the Ardennes (Triantafyllou et al. 2019), or those covered with dense vegetation preventing surface studies, such as the South China fold belt (Szczygieł et al. 2018). Moreover, since the preservation of surface outcrops within mid-sized European mountains is far from perfect, caves appear to contain outcrops with a high level of potential for structural analysis. In particular, in caves, the geologist is surrounded by outcrops, making it possible, in fault-controlled systems, to follow fault planes for up to hundreds of meters (Szczygieł 2015a, b). Furthermore, stable conditions in caves preserve slickensides from long-term erosion effect, rendering them suitable for structural analysis (Szczygieł et al. 2015; Triantafyllou et al. 2019).

In this paper, we present the first results of a paleostress investigation of fault planes within the Niedźwiedzia Cave 
in the Śnieżnik Massif (Sudetes, NE Bohemian Massif), including data from newly-discovered Mastodont parts (see Sobczyk et al. 2016), to discuss Meso-Cenozoic stress history recorded within the Sudetic segment of the European Variscides. Our paleostress analyses, supplement paleostress data for the entire NE Bohemian Massif (Adamovič and Coubal 1999; Pešková et al. 2010; Coubal et al. 2015; Nováková 2014, 2015, 2016; Stemberk et al. 2019). Available so far reconstructions for the stress field evolution in the Sudetes, instead of widely discussed Variscan tectogenesis (see e.g., Aleksandrowski et al. 1997), only rarely concern post-Variscan stress history based i.a. on fault planes kinematic indicators (Cymerman 1993) and conjugate cataclastic zones (Solecki 1994). This situation was partly the effect of limited interest to neoformed brittle structures, resulting in a few individual regional studies, e.g., from North Sudetic Basin (Kowalski 2020), Hronov-Poříčí Fault Zone (Nováková 2014), eastern sectors of Sudetic Marginal Fault (Pešková et al. 2010; Nováková 2015, 2016) and Rychlebske Hory Mts. (Stemberk et al. 2019). At the same time, presented results of detailed structural mapping in the Sudetes (Cymerman 1995) have not provided insights into paleostress history, whereas literature overviews were mainly focused on principal structural investigations in relation to Variscan history (Oberc 1972), with less attention paid to younger, brittle structures. Incidentally reported in the literature Alpine events controlling Sudetes rebuilding, were interpreted most likely on field observation and shallow drilling, with no regular study of stress kinematic indicators (Cymerman 1990; Kozdrój 2014; Badura and Rauch 2014). In this context, faults recorded in Niedźwiedzia Cave provide interesting insights into scraps of stress field history of the Sudetic Block, that remain underrated.

\section{Geology (Variscan orogen and Alpine tectonics)}

The Sudetes represent a part of the Variscan orogenic belt at the NE tip of the Bohemian Massif, consolidated during the Late Devonian-Carboniferous climax of orogenic processes (Mazur et al. 2010), as defined in an extensive consolidated geochronological data set (see Sobczyk et al. 2015 and references therein). Their structural history in terms of Variscan orogenesis has been the subject of numerous studies (e.g., Mazur et al. 2010 and references therein), resulting in the conceptualization of tectonic suture zones within the microplate framework of the Sudetes (see Mazur and Aleksandrowski 2001; Mazur et al. 2005, 2012). Notably, semi-brittle to brittle Late Variscan syn-orogenic strike-slip tectonics occurring along with major faults and shear zones in the Sudetes resulted in regional structural reorganization and movements of up to hundreds of kilometers by various units (Aleksandrowski et al. 1997). The post-Variscan geological history of the Sudetes is dominated by Permo-Mesozoic volcano-sedimentary succession (Awdankiewicz et al. 2007) that culminated during the Cretaceous sea transgression preceding the Late Cretaceous-Paleogene basin inversion. Numerous prior studies (Sobczyk et al. 2020 and references therein) have concluded that the onset of the last vast differential tectonic movements within the area of the Śnieżnik Massif and Orlica-Śnieżnik Dome (OSD) should be referred to Miocene reactivation of Sudetic crustal blocks. Dyjor (1975), for example, suggested that the onset of the last phase of intense tectonic uplift in the Sudetes started in the Oligocene and reached its maximum during the Pliocene. During this period, the most significant movements resulted in displacements of 500-1000 m, recorded mainly along with major tectonic structures, represented, e.g., by the Upper Nysa Kłodzka Graben (UNKG) boundary faults and Sudetic Marginal Fault (Fig. 1; Badura et al. 2007). Don (1989) linked Late Cenozoic tectonic movements with the formation of step-like planation levels. Badura and Rauch (2014) suggested that Quaternary vertical displacements along the fault-bounded UNKG were in the range of 50-100 m. Additionally, Dumicz (1964) claimed the existence of two fault systems in the westernmost OSD area with loosely bracketed ages younger than the Late Cretaceous and displacement in the range of tens of metres. However, none of these studies is supported by any geochronological data, hence faulting activity in the Sudetes remains still unconstrained. Rough estimations regarding the size and scale of post-Variscan tectonics might be indirectly derived from fission-track thermochronometric data presented for the entire OSD area by Sobczyk et al. (2020). These authors interpreted inversely modelled thermal history paths to reflect a total of 3-3.5 km of exhumation since 60-70 Ma, which can be divided into two separate cooling events, Coniacian-Santonian (initial phase), Late Cretaceous-Paleogene (main phase), followed by final exhumation since the Tortonian ( 10 Ma). The last-mentioned exhumation episode, in particular, corresponds loosely to the models proposed by Dyjor (1975).

\section{Niedźwiedzia Cave}

Niedźwiedzia Cave is located on the western slopes of Stroma Mt. (1166 m a.s.l.) in the Śnieżnik Massif (Sudetes), within the deeply-incised (300-500 m) Kleśnica River valley. Cave passages represent a system of mainly horizontally elongated conduits, and chambers concentrated on three cave levels, only locally replaced by vertical shafts and chimneys (Fig. 2). Niedźwiedzia Cave evolved within a supracrustal unit of the Stronie Formation of the Late Proterozoic-Early Cambrian (Gunia 1997; Mazur et al. 2012) or alternatively Middle Cambrian-Early Ordovician ages (Jastrzębski et al. 2010). The Stronie Formation, which constitutes the eastern part of the OSD, comprises a set of crystalline 

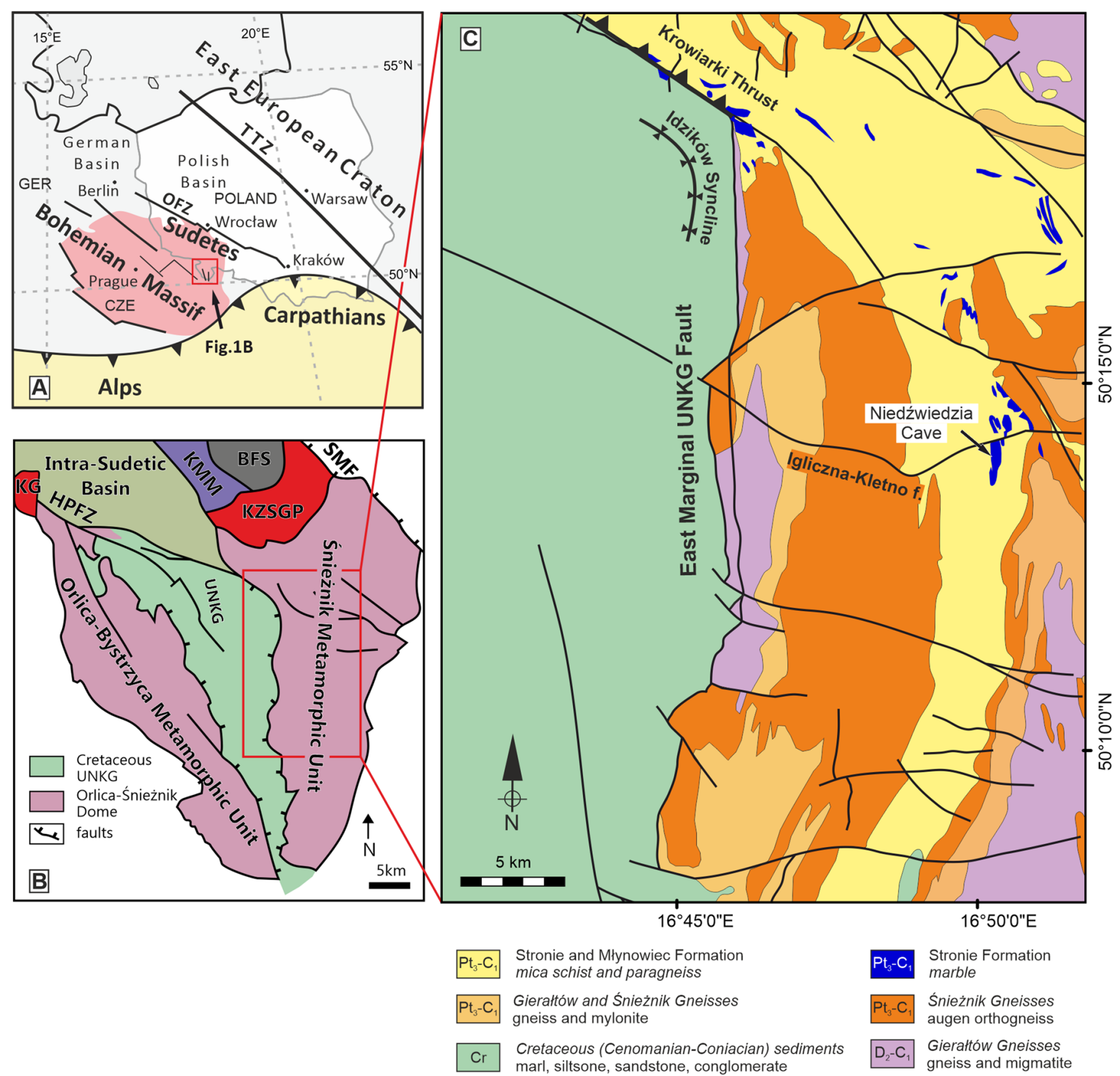

Fig. 1 Location of the study area in the Bohemian Massif (a) and Sudetes (b). c Geological map of the eastern Orlica-Śnieżnik Dome with location of Niedźwiedzia Cave (modified after Don et al. 2003). a OFZ: Odra Fault Zone, TTZ: Teisseyre-Tornquist Zone; b KG:

nappes built of low- to high-grade metamorphic rocks (Don and Opletal 1997; Chopin et al. 2012). The Stronie Formation contains strongly folded mica schists, paragneisses, amphibolite, quartzite, and marbles, formed as a result of polyphase metamorphic processes related to greenschist and amphibolite facies conditions (Koszela 1997) during the initial stage (350-330 Ma) of Variscan orogenesis (Jastrzębski 2008). The Niedźwiedzia Cave system evolved within the marbles of the Stronie Formation, which form a narrow in
Kudowa Granite, KU: Kłodzko Metamorphic Massif, BFS: Bardo Fold Structure, KZSGP: Kłodzko-Złoty Stok Granite Pluton, UNKG: Upper Nysa Kłodzka Graben, HPFZ: Hronov-Poříčí Fault Zone, SMF: Sudetic Marginal Fault

the Kletno area, lenticular body rimmed with mica-schists and paragneisses, and are characterized by various dolomite admixtures. During the Cenomanian, in the central part of the OSD, a new tectonic unit of the UNKG originated as a result of the local extension, preceding fault-block movements and basin inversion, generally linked with the Subhercynian tectonic phase (Don 1996; Sobczyk et al. 2020). Brittle tectonic structures in the OSD area have attracted less attention; their age and origin remain a matter of debate 
Fig. 2 Structural sketch of the Niedźwiedzia Cave in Kletno (cave morphology adopted after Kostka 2014); FZ I- FZ VI refer to fault zones described in results

(see Kasza 1964; Don 1964; Dumicz 1964; Cymerman 1997). For example, Kontny et al. (2005), using the longterm record of microtectonic extensometric measurements in the Sudetes, concluded that fault planes analyzed in the Niedźwiedzia Cave exhibited a general trend of NW-SE compressional stresses. They also reported prolonged relative movements $(<0.1 \mathrm{~mm} /$ year $)$ of the fault zones and the possible influence of far-field earthquakes on distractions in the time series record. In this context, the fault-plane-derived paleostress dataset presented here for the Niedźwiedzia Cave gives the first impression of a tectonic regime and a sense of movement, with a possible deviation of the stress field between WNW to NW sectors.

\section{Materials and methods}

The fieldwork included orientation measurements of fault planes and slickensides with kinematic indicators. Faults core width, surface roughness, and spacing between neighboring planes were investigated to estimate a displacement scale and discuss the potential regional importance of each structure. In total, 22 faults, along with their accompanying structures, were documented in Niedźwiedzia Cave (Fig. 3, 4). To obtain homogeneous stresses for each set of faults, data were manually subdivided based on a sense of motion and orientation: (1) dextral W-E striking (13 faults), (2) sinistral W-E striking (6 faults), and (3) dextral N-S striking (3 faults). Fault-slip data were used to reconstruct the paleostress fields, defined by the orientation of the stress axes: principal maximum compression axis, $\sigma 1$; principal intermediate compressional axis, $\sigma 2$; principal minimum compressional axis, $\sigma 3$; where $\sigma 1>\sigma 2>\sigma 3$. The reconstruction was performed according to the standard procedure, applying two widely used methods: Dihedra (Angélier and Mechler 1977) and inverse (PBT) (Angélier et al. 1982; Delvaux and Sperner 2003). Both methods are based on the calculation of stress tensors for individual faults and a "fitting" stress tensor which can potentially be adapted to all considered faults, referred to here as a reduced stress tensor. Our best-fit criterium was the angle of deviation between a given slickenline and the computed reduced stress tensor of $<30^{\circ}$ (see Ramsay and Lisle 2000; Delvaux and Sperner 2003). In the inverse method, the stress ratio $\Phi$ or $R[\Phi=(\sigma 2-\sigma 3) /(\sigma 1-\sigma 3)]$ is calculated by defining the stress ellipsoid (for further details see Ramsay and Lisle 2000). Both procedures were conducted in TENSOR software (Delvaux 1993), including the recent contribution to the software made by Delvaux and Sperner (2003), i.e., adding a stress regime index $R^{\prime}$. In brief,

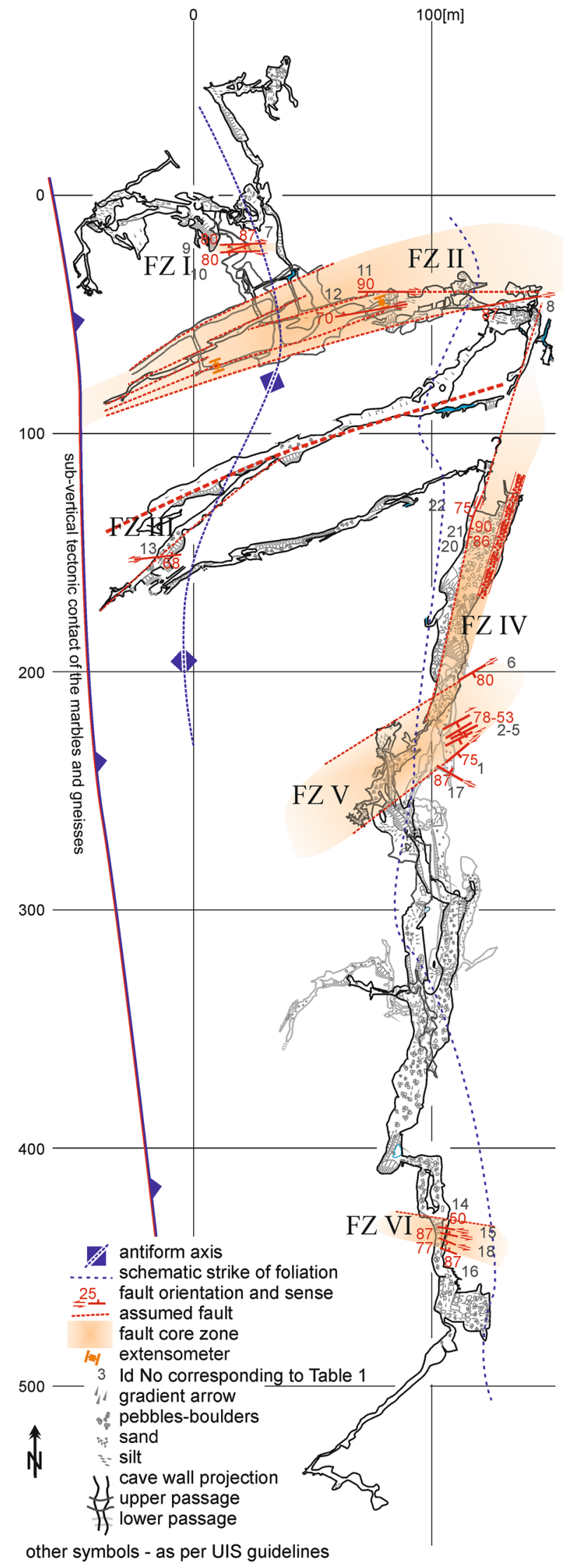




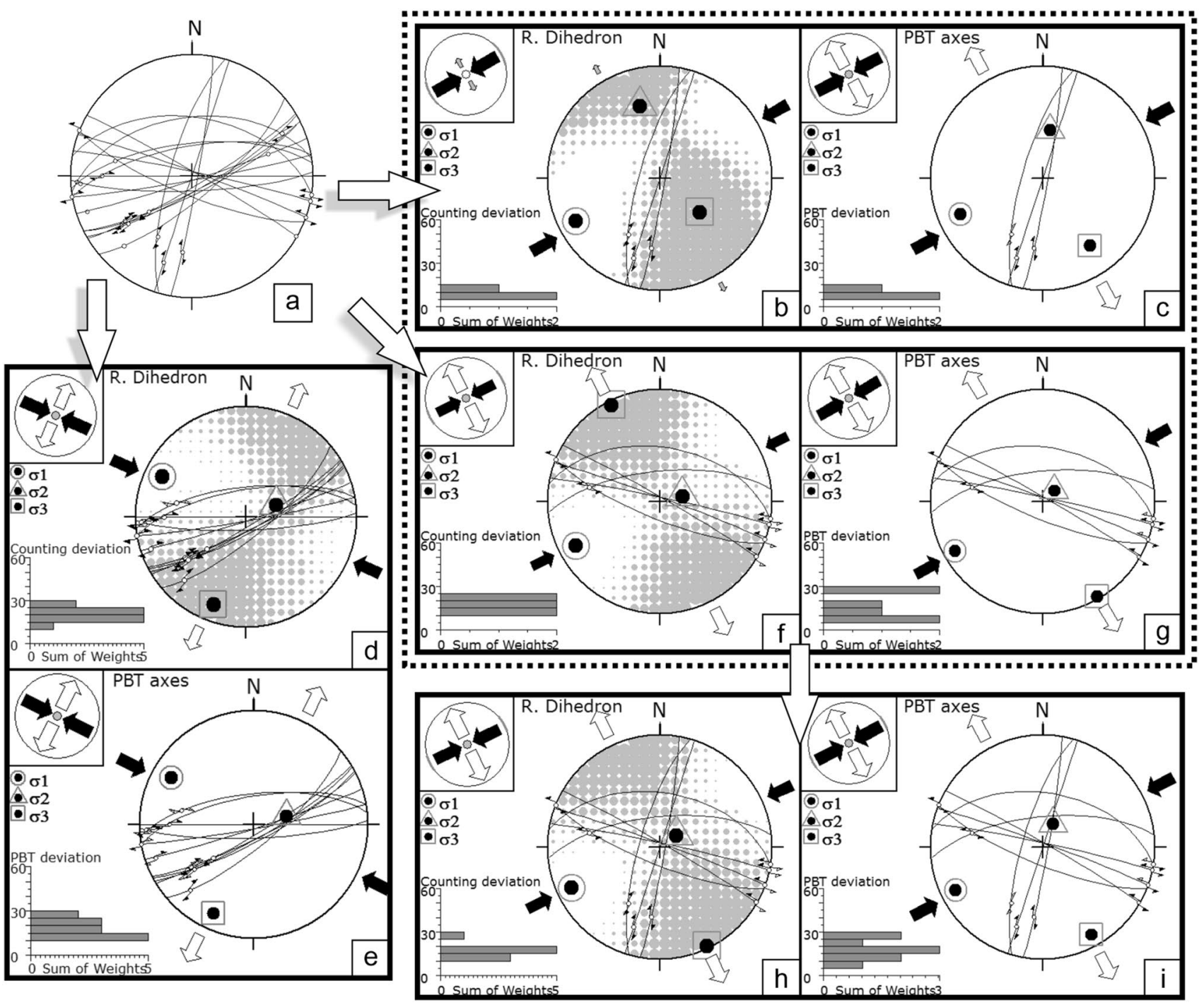

Fig. 3 Fault slip data and paleostress reconstruction results computed from both methods: Dihedra (b, d, f, h) and PBT (c, e, g, i); a population of all analyzed faults; $\mathbf{b}, \mathbf{c}$ set $3 ; \mathbf{d}$, e set $1 ; \mathbf{f}, \mathbf{g}$ set $2 ; \mathbf{h}$, $\mathbf{i}$ set 4 as a resultant set 2 and 3 ; numerical values are summarized in Table 2

$R^{\prime}$ is expressed numerically within the range $0-3$. The stress regime is: extensional, if $R^{\prime}=R$ and $\sigma 1$ is vertical; strike-slip, if $R^{\prime}=2-R$ and $\sigma 2$ is vertical; compressional, if $R^{\prime}=2+R$ and $\sigma 3$ is vertical (see Delvaux et al. 1997). For regionalscale comparison, especially in a map view, $\mathrm{SH}$ (maximum horizontal compression axis) and Sh (minimum horizontal compression axis) were computed (for details, see Delvaux and Sperner 2003).

\section{Results}

\section{Faults characteristics}

In the Niedźwiedzia Cave, we have localized six different fault zones (FZ) numbered I to VI from $\mathrm{N}$ to $\mathrm{S}$ with associated brittle structures used for paleostress analysis (Fig. 2). Starting from the northernmost part of the cave, FZ I intersects along the W-E strike cave's passages, controlling ipso facto cave pattern. FZ I has a $3 \mathrm{~m}$ wide fault core zone, bounded by parallel minor faults, with nearly flat (ca. $1-\mathrm{cm}$ steps), at mesoscale, planes and R-type Riedel shears with slickensides. Marbles within a fault core are strongly tectonized, with a system of dense fractures, although neither cataclasites nor breccia have been documented.

FZ II is one of the largest and most prominent tectonic zone in the cave that runs across the strike of Kleśnica river valley (W-E) and has been observed both in lower and middle cave levels. Importantly, from the middle cave level, results of extensometer micro-displacement monitoring have been reported (i.a. Mąkolski et al. 2008; Stemberk et al. 2010). This fault zone is characterized by ca. $25-30 \mathrm{~m}$ wide 


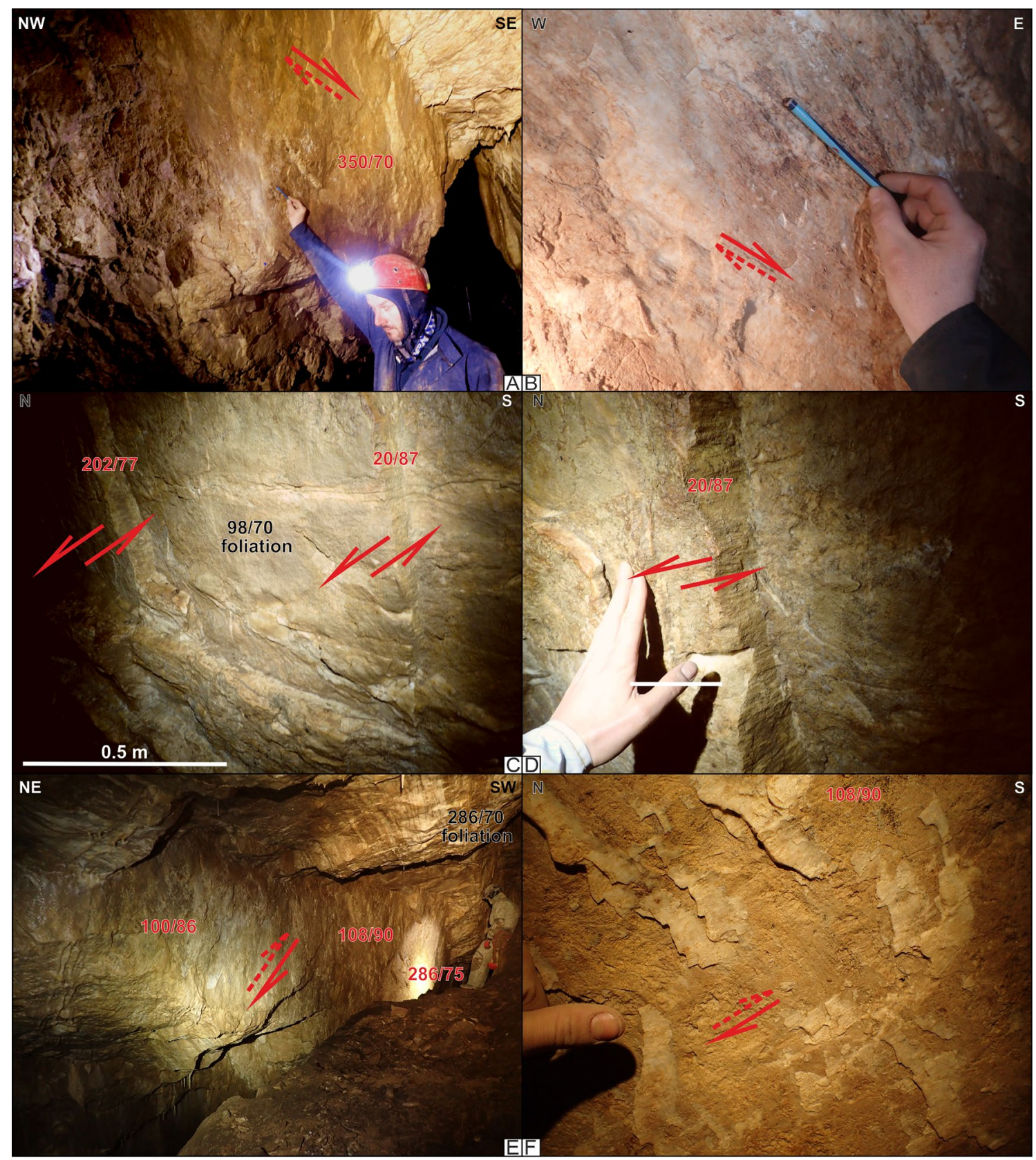

Fig. 4 Examples of recorded faults of set $1(\mathbf{a}, \mathbf{b})$, set $2(\mathbf{c}, \mathbf{d})$, and set $3(\mathbf{e}, \mathbf{f})$; picture on the right is a zoom-in of the left image

multiple fault core setting (Faulkner et al. 2010), wherein we recognized three individual fault planes with slickensides, all with dextral kinematics nature. Every documented fault plane contained steps and slickensides with undulated linear roughness defined by ridges and grooves of varying coarseness. No breccia was found, however, observed joint cleavage often hinder foliation recognition. Fracture density increase toward the fault plane surface, being eventually replaced by R'-type Riedel shears.

FZ III runs WSW-ENE and does not contain well-preserved kinematic indicators of tectonic activity. For this zone, we interpret cave passage walls as synonymous with the fault plane. The wall is characterized by smooth surfaces with no distinguishable linear roughness, and only one minor fault plane containing a sinistral sense of movement kinematic indicators was documented. Nevertheless, cave morphology coincides strongly with this tectonic zone, which is well expressed by up to $20 \mathrm{~m}$ deep fissure forming cave passage, that runs obliquely to regional foliation trend (Fig. 2).

Within the FZ IV well-exposed sinistral NNE strikeslip fault was recognized. This structure has a significantly 
different character than any other documented tectonic feature within the cave. Importantly, this zone also controls the dominant orientation of the Mastodont Chamber and, to some extent, overlap with the westernmost cave wall. Observed here ca. $20 \mathrm{~m}$ in width fault core is slightly fractured with a well-preserved foliation. Documented fault planes are characterized by undulated surface and $2-3 \mathrm{~m}$ wavelength. Planes strike changes in the range of $\sim 15^{\circ}$, which suggests that at the initial stage of fault activity they formed as Riedel shears, smoothened afterward due to rock mass displacement (Sagy et al. 2007). In the mesoscale, fault surface is polished with slickensides preserved on mineralized, millimeter-scale steps. One of the fault surfaces was documented and traced for $\sim 120 \mathrm{~m}$ horizontally and ca. $20 \mathrm{~m}$ in vertical extent. This zone is also characteristic because of the massive collapse with $>10 \mathrm{~m}$ wide rock boulder, which was detached along the, now exposed, fault plane. In the eastern part of the FZ IV within the Mastodont Chamber a ca. $4 \mathrm{~m}$ wide breccia zone was documented, with individual clasts reaching up to $0.5 \mathrm{~m}$ in diameter (partly rotated). Interestingly, a few centimetres thick fault gouge layer was found in the southernmost part of the chamber on the ex-situ collapsed boulder.

FZ V represents a set of localized fault planes striking NE and steeply dipping to the SE. The fault core zone here is $\sim 25 \mathrm{~m}$ wide. Individual fault planes are parallel and closely spaced $(0.5-3 \mathrm{~m})$, with millimeter-scale slickensides defined by grooves indicating a dextral sense of movement. Within this zone, neither breccia nor gouge has been found; however, the high fracture density allows identifying the fault core unambiguously. Considering the coincident nature of FZ IV and FZ V zones, the latter one might be suspected of being a tip or linking damage zone, however, both their mutual orientation and recognized sense of movement do not follow known schemes (see Kim et al. 2004).

FZ VI forms a set of localized, W-E striking fault planes within a ca. $15 \mathrm{~m}$ wide fault core. Individual fault planes are closely spaced $(0.5-1 \mathrm{~m})$, with millimeter-scale sized slickensides defined by grooves indicating a sinistral sense of movement. Fractures within the fault core are less dense than within the other zones, with no breccia nor gouge identified.

\section{Faults displacement}

Since there are no observable marker horizons on both sides of fault zones within the Niedźwiedzia Cave, we were not able to unambiguously determine fault displacement. As mentioned earlier, also there is no clear evidence of fault movement after cave formation, such as displaced dissolution morphology, e.g. like in the Tatra Mts (Szczygieł 2015b).

However, many attempts have been made to estimate the scale of displacement including such fault properties as roughness (e.g., Power et al. 1988; Sagy et al. 2007; Brodsky et al. 2011), length (Kim and Sanderson 2005 and references therein), and width (of damage or core zone; e.g., Mitchell and Faulkner 2009; Torabi and Berg 2011), in the case of Niedźwiedzia Cave, the only parameter that can be determined is a fault core width. Taking into account the limited character of our data, we can at most estimate an order of magnitude for the probable displacements. Although every particular fault core derived from the fault damage zone should have, if possible, a microtectonic analysis (Mitchell and Faulkner 2009), we were able to macroscopically limit the core to parallel, closely spaced fault planes. Next, we used those as our best estimation of the minimum fault core thickness. Following this idea, the total displacement of the fault zone would be represented by the sum of the individual localized fault planes offset.

Considering the distinct trace of FZ I and FZ II both in surface morphology and cave pattern as well as their importance as regional stress transfer zones (Stemberk et al. 2010), they may represent a portion of higher-order Igliczna-Kletno fault zone (Fig. 1c) bounding marble lens to the north. Basing on UNKG and OSD contact offset along this fault zone localized to the $\mathrm{W}$ from Niedźwiedzia Cave, the magnitude of horizontal displacement may be roughly estimated at ca. $1 \mathrm{~km}$ (Fig. 1).

Analyzing FZ V and FZ VI zones and using a relationship between fault displacement and fault core thickness (Torabi and Berg 2011), we roughly estimate the magnitude of displacement for these zones within the order of tens of meters. Fault core thickness of FZ IV is even more ambiguous. On the one hand, there is only one undulating localized fault plane; on the other hand, the $4 \mathrm{~m}$ thick breccia implies a significant displacement. We conservatively limited the fault core zone from the fault plane to the west to the eastern end of the brecciated marbles for our estimation. Accepting the limitation mentioned above, the FZ IV core's width reaches $20 \mathrm{~m}$, which might be translated into tens to over a hundred meters of fault wall displacement (see Torabi and Berg 2011).

\section{Paleostress reconstruction}

Three distinguished fault sets (set 1: dextral W-E; set 2: sinistral $\mathrm{W}-\mathrm{E}$; set 3: dextral $\mathrm{N}-\mathrm{S}$ ) were subjected to analysis using the Dihedra and inverse methods. Principal axes orientation calculated from each fault-slip data, along with $\mathrm{SH}, \mathrm{Sh}$, and $R^{\prime}$, are presented in Table 1; results of the computation of the stress field related to fault sets are shown in Fig. 3. Since the results for sets 2 and 3 are similar, we computed final stress field values using the sum of these sets, which produced similar results. Accordingly, we interpreted the population composed of sets 2 and 3 as a single consistent population, subsequently designated set 
Table 1 Results of stress field reconstruction of individual faults with PBT method

\begin{tabular}{|c|c|c|c|c|c|c|c|c|c|c|c|c|c|c|}
\hline \multirow[t]{2}{*}{ Id } & \multicolumn{2}{|c|}{ Fault plane } & \multicolumn{2}{|c|}{ Slip line } & \multirow{2}{*}{$\begin{array}{l}\text { Slip } \\
\text { Sense }\end{array}$} & \multicolumn{2}{|c|}{ Sigma 1} & \multicolumn{2}{|c|}{ Sigma 2} & \multicolumn{2}{|c|}{ Sigma 3} & \multirow{2}{*}{$\begin{array}{l}S_{\mathrm{H}} \\
\text { Azimuth }\end{array}$} & \multirow{2}{*}{$\begin{array}{l}S_{\mathrm{h}} \\
\text { Azimuth }\end{array}$} & \multirow[t]{2}{*}{$R^{\prime}$} \\
\hline & Dip & Dip dr & Plunge & Azimuth & & Incl & Azimuth & Incl & Azimuth & Incl & Azimuth & & & \\
\hline 1 & 75 & 140 & 21 & 224 & ND & 26 & 273 & 64 & 83 & 4 & 181 & 92 & 2 & 1,5 \\
\hline 2 & 80 & 153 & 34 & 236 & ND & 31 & 290 & 54 & 77 & 16 & 190 & 104 & 14 & 1,0 \\
\hline 3 & 80 & 153 & 34 & 236 & ND & 31 & 290 & 54 & 77 & 16 & 190 & 104 & 14 & 1,0 \\
\hline 4 & 78 & 152 & 30 & 235 & ND & 30 & 287 & 57 & 81 & 12 & 190 & 103 & 13 & 1,5 \\
\hline 5 & 83 & 149 & 52 & 230 & ND & 40 & 295 & 37 & 64 & 28 & 178 & 100 & 10 & 1,0 \\
\hline 6 & 80 & 150 & 35 & 233 & ND & 32 & 287 & 53 & 74 & 16 & 187 & 101 & 11 & 1,0 \\
\hline 7 & 87 & 162 & 10 & 251 & ND & 9 & 297 & 80 & 88 & 5 & 206 & 117 & 27 & 1,5 \\
\hline 8 & 87 & 170 & 0 & 260 & ND & 2 & 305 & 87 & 170 & 2 & 35 & 125 & 35 & 1,5 \\
\hline 9 & 80 & 178 & 9 & 266 & ND & 13 & 312 & 76 & 135 & 1 & 42 & 132 & 42 & 1,5 \\
\hline 10 & 80 & 178 & 6 & 267 & ND & 11 & 312 & 78 & 146 & 3 & 43 & 132 & 42 & 1,5 \\
\hline 11 & 90 & 180 & 27 & 270 & ND & 19 & 318 & 63 & 90 & 19 & 222 & 135 & 45 & 1,5 \\
\hline 12 & 70 & 350 & 0 & 260 & ID & 14 & 123 & 70 & 350 & 14 & 217 & 125 & 35 & 1,5 \\
\hline 13 & 68 & 354 & 36 & 281 & ID & 9 & 320 & 46 & 59 & 43 & 222 & 137 & 47 & 2,0 \\
\hline 14 & 50 & 9 & 0 & 99 & $\mathrm{~S}$ & 27 & 242 & 50 & 9 & 27 & 136 & 54 & 144 & 1,5 \\
\hline 15 & 87 & 12 & 0 & 102 & $\mathrm{~S}$ & 2 & 237 & 87 & 12 & 2 & 147 & 57 & 147 & 1,5 \\
\hline 16 & 87 & 20 & 0 & 110 & $S$ & 2 & 245 & 87 & 20 & 2 & 155 & 65 & 155 & 1,5 \\
\hline 17 & 87 & 30 & 1 & 120 & $\mathrm{~S}$ & 1 & 255 & 87 & 12 & 3 & 165 & 75 & 165 & 1,5 \\
\hline 18 & 77 & 202 & 0 & 292 & $\mathrm{~S}$ & 9 & 68 & 77 & 202 & 9 & 336 & 67 & 157 & 1,5 \\
\hline 19 & 68 & 354 & 36 & 281 & NS & 43 & 222 & 46 & 59 & 9 & 320 & 47 & 137 & 1,5 \\
\hline 20 & 86 & 100 & 37 & 187 & $\mathrm{D}$ & 28 & 240 & 53 & 15 & 22 & 137 & 53 & 143 & 1,5 \\
\hline 21 & 90 & 108 & 26 & 198 & $\mathrm{D}$ & 18 & 246 & 64 & 18 & 18 & 150 & 63 & 153 & 1,5 \\
\hline 22 & 75 & 286 & 42 & 209 & D & 17 & 253 & 44 & 1 & 41 & 148 & 67 & 157 & 1,5 \\
\hline
\end{tabular}

$N$ normal, $I$ inverse, $D$ dextral, $S$ sinistral, Dip $d r$ dip direction, $S_{\mathrm{H}}$ maximum horizontal compression axis, $S_{\mathrm{h}}$ minimum horizontal compression axis

4. Stress regime index $R^{\prime}$ values computed for individual fault sets using the Dihedra method range fell between 1.38 to 1.55 ; using the PBT method, between 1.45 and 1.52. A combined value of $R^{\prime}$ data, subvertical $\sigma 2$, and stress ratio $\mathrm{R}$ close to 0.5 suggests a pure strike-slip paleostress tensor. Slickenside data from 22 faults identified in marble within the Niedźwiedzia Cave grouped into subsets for tectonic stress inversion revealed two main contraction phases for kinematic evolution: (1) NE-SW oriented, and (2) WNW-ESE oriented.

\section{Discussion}

We reconstructed local paleostress fields for the eastern part of the OSD, using fault-slip data. Individual fault population datasets revealed two significantly different paleostress

Table 2 Paleostress tensors from fault-slip data

\begin{tabular}{|c|c|c|c|c|c|c|c|c|c|c|c|c|}
\hline \multirow[t]{2}{*}{ Set } & \multirow[t]{2}{*}{ Method } & \multicolumn{2}{|c|}{ Sigma 1} & \multicolumn{2}{|c|}{ Sigma 2} & \multicolumn{2}{|c|}{ Sigma 3} & \multirow{2}{*}{$\begin{array}{l}S_{\mathrm{H}} \\
\text { Azimuth }\end{array}$} & \multirow[t]{2}{*}{$R$} & \multirow[t]{2}{*}{$R^{\prime}$} & \multirow[t]{2}{*}{ Mean deviation } & \multirow[t]{2}{*}{ Max deviation } \\
\hline & & Dip & Azimuth & Dip & Azimuth & Dip & Azimuth & & & & & \\
\hline \multirow[t]{2}{*}{1} & Dihedra & 17 & 296 & 66 & 069 & 16 & 200 & 113 & 0.38 & 1.50 & 20.3 & 28.5 \\
\hline & PBT & 19 & 300 & 66 & 076 & 13 & 203 & 116 & 0.50 & 1.50 & 18.3 & 26.5 \\
\hline \multirow[t]{2}{*}{2} & Dihedra & 16 & 242 & 73 & 077 & 04 & 333 & 063 & 0.67 & 1.38 & 16.3 & 23.3 \\
\hline & PBT & 11 & 241 & 79 & 047 & 03 & 150 & 060 & 0.55 & 1.45 & 16.9 & 28.1 \\
\hline \multirow[t]{2}{*}{3} & Dihedra & 17 & 243 & 33 & 345 & 51 & 130 & 060 & 0.17 & 1.55 & 9.9 & 11.4 \\
\hline & PBT & 21 & 246 & 54 & 009 & 27 & 145 & 061 & 0.49 & 1.51 & 8.8 & 11.0 \\
\hline \multirow[t]{2}{*}{4} & Dihedra & 14 & 245 & 75 & 054 & 03 & 155 & 065 & 0.56 & 1.38 & 16.7 & 25.0 \\
\hline & PBT & 14 & 244 & 71 & 024 & 11 & 151 & 062 & 0.48 & 1.52 & 18.0 & 29.2 \\
\hline
\end{tabular}


regimes of unconstrained age: P2 (sets 2-4 in Table 2) represented by a general NE-SW direction, and P1 (set 1 in Table 2) expressed by the WNW-ESE orientation of the maximum principal stress axis (Fig. 5). Since we had no direct field evidence of age relationships for fault data populations, we based our discussion on a comparison with available paleostress data for the entire NE Bohemian Massif supplemented with regional field data (i.e., Adamovič and Coubal 1999; Don et al. 2003; Uličný et al. 2009; Pešková et al. 2010; Coubal et al. 2015; Nováková 2014, 2015; Stemberk et al. 2019; Kowalski 2020; Roštínský et al. 2020). For both systems, one of the essential recent tectonic events may have been the Meso-Cenozoic faulting of the UNKG and OSD (i.e., the Krowiarki Marginal Fault and Igliczna-Kletno fault; Fig. 1c). This tectonic event resulted in widespread (Don 1996; Reicherter et al. 2008) activation of NE Bohemian Massif crustal blocks, which, at the end of the Cretaceous and Paleogene, were unevenly exhumed from depths of 3-6 km (see Sobczyk et al. 2020). Moreover, due to the orientation $\alpha \sim 60^{\circ}$ between the graben trend and the general compression axis derived from paleostress data reconstruction, we hypothesize that faults found within the Niedźwiedzia Cave may represent planes associated with two-phase Late Cretaceous-Cenozoic strike-slip tectonics (see also Brun and Nalpas 1996 for details) controlling latest paroxysms of OSD and UNKG structural rebuilding. This process resulted in a dextral strike-slip offset of Cretaceous strata along i.a. the Igliczna-Kletno fault. Noteworthy, none of the analyzed planes revealed E-W directed extension to be associated with the $\mathrm{N}-\mathrm{S}$-striking Upper Nysa Kłodzka Graben formation.

Nowadays, recent seismicity $(M \sim 4.7)$ in the research area is related mainly to the WNW-ESE-trending HronovPoříčí Fault Zone (HPFZ) (Nováková 2014; Špaček et al.

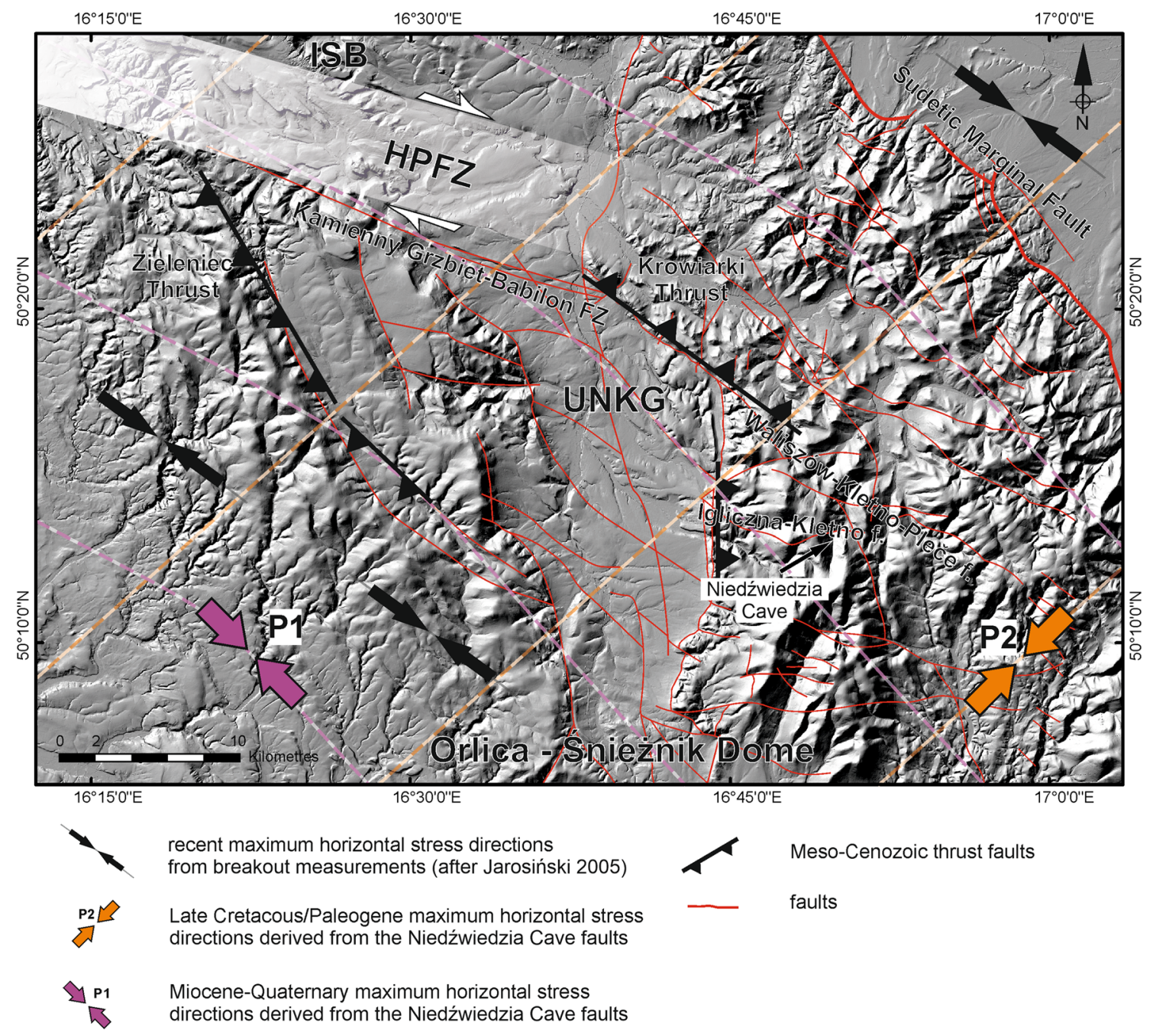

Fig. 5 LiDAR-based digital terrain model of the OSD and UNKG area with a summary of kinematic data derived from the Niedźwiedzia Cave supplemented with recent shortening directions from breakout measurements 
2006, 2015), which coincides with geological unit boundaries within the Intra-Sudetic Basin (Fig. 1). In its easternmost part, the HPFZ system is parallel to the WNW-ESEtrending, sinistral strike-slip Kamienny Grzbiet-Babilon Fault Zone (Don and Gotowała 2008), obliquely cutting the UNKG to the north. This fault zone continues farther to the E of the graben axis with the NW-SE oriented Krowiarki Marginal Fault (Krowiarki Thrust), which to the SE is represented by the Waliszów-Kletno-Pleče fault (Don et al. 2003). In this form, Niedźwiedzia Cave is located along the strike of a vast tectonic (seismic) zone (Fig. 5), which continues (W) NW-(E)SE for $\sim 100 \mathrm{~km}$ throughout the Sudetes. Therefore, the paleostress strike-slip indicators of the WNW-ESE directions recorded in Kletno may be linked with the reported WNW-ESE right-lateral motion within the HPFZ (Nováková 2014). Boundary faults of the UNKG are cut obliquely to the $\mathrm{N}$ by this tectonic zone and produce a sinistral (sense of shear) strike-slip offset of N-S trending graben boundaries, believed to be Cenozoic in age (Don and Gotowała 2008). Analysis of joints systems mapped by Cymerman (1995) both for Palaeozoic crystalline basement and Mesozoic sedimentary rocks in the research area indicates their congenial orientation, which might be interpreted e.g. as a result of a similar regional stress field. For the Cretaceous sedimentary rocks of the Intra-Sudetic Basin (ISB) Jerzykiewicz (1968) suggested that joints represent structural planes predating strata deformation (folding and faulting). Concerning the results of apatite fission-track dating (Sobczyk et al. 2020) onset of strata folding is bracketed to Campanian-Maastrichtian ( 75-70 Ma), therefore, observed joints systems must be pre-Campanian at minimum. Consequently, assuming burial depths in the UNKG and ISB exceeding $3 \mathrm{~km}$ during Coniacian-Campanian and rising NE-SW oriented contractional stresses, one might expect joints system formations in the upper-crust levels, both in metamorphic and sedimentary rocks. In addition, coherent paleostress data from the Central European Basin System (Sippel et al. 2009) support a view of rock age-independent post-Cenomanian uniform deformation of the upper crust.

Accordingly, because fault planes in Niedźwiedzia Cave originated mainly along a system of joints (Fig. 4), we associate faults discussed here with Subhercynian and younger tectonic activity. In other words, Niedźwiedzia Cave faults originated along pre-existing shallow (3-5 km deep) weakness planes and evolved in a brittle (transpressional?) regime during the Late-Cretaceous/Palaeogene. This phase is claimed to be the most important horizontal contractional event during the last 70-90 Ma across Central Europe (Kley 2018), as a direct response to intraplate stresses transferred mainly at this time from W Europe (Kley and Voigt 2008). Hence, at a minimum, strike-slip faults observed within Cretaceous Bohemian Basin formations should be associated with Late Cretaceous (Subhercynian)-Paleogene tectonic activity. This argument is congruent with field observations from the Sudetes Cretaceous basins, where strike-slip faults are commonly reported and interpreted as a result of general horizontal contraction (e.g., Don and Gotowała 2008; Nováková 2014), locally, as an exception to the rule, replaced by transtensional stresses (Kowalski 2017). Consequently, paleostress population $\mathrm{P} 2\left(\sigma 1 \sim 240^{\circ}\right)$ may reflect a record of a Late Cretaceous-Middle Eocene compressional stress field identified as indicative in the case of, e.g., the origin of the Elbe Fault System in the NW Bohemian Massif (Adamovič and Coubal 1999; Coubal et al. 2015) and graben structures formation in the North Sudetic Basin (Kowalski 2020). Equally, depending on regional structural trends accommodating stress transfer within the Sudetic Block during the $\mathrm{P} 2$ phase, some local stress field deviations cannot be excluded.

The stratigraphically documented inception horizon of the UNKG inversion is traditionally referred to Coniacian conglomerates of the upper Idzików beds (Don and Don 1960; Don 1996), with the first signals of an inversion occurring during the Coniacian-Maastrichtian. The observed dragging of N-S- trending Idzików beds in the UNKG boundary zone suggests an E-W transport direction for the eastern OSD area. Combining the above data, the paleostress axes inferred from faults in Niedźwiedzia Cave in Kletno located ca. $10 \mathrm{~km}$ east of the UNKG may represent NE-SW stress tensors formed during UNKG (stress record oblique to the UNKG) inversion and later. However, it cannot be unequivocally excluded, that some portion of faults represents reactivated structures evolved on inherited end-Variscan planes, as was proposed for some faults in the western OSD (Dumicz 1964). In addition, the Triassic-Jurassic age of planes cannot be unambiguously excluded since few zircons from the Western Sudetes (Sobczyk et al. 2015) analyzed with (U-Th/ $\mathrm{He}$ ) method revealed 250-170 Ma cooling ages, which was explained i.e., as a signal of regional tectonic uplift.

The possible neotectonic activity of the research area represents a different problem. In the case of the Niedźwiedzia Cave, if analyzed faults were active during Late Quaternary (Middle Pleistocene-recent), we would expect visible displacements, such as those in caves in the Tatras (Szczygieł 2015b) or Eastern Alps (Baroň et al. 2019). Therefore, there should be evidence of voids shifting, especially in the highest, oldest level of the Niedźwiedzia Cave; however, no such displacements have been recorded. On the other hand, large collapses in the whole cave (Fig. 2) may suggest the occurrence of tectonic displacements that triggered breakdown and obliterated voids shifts. In fact, the age of Niedźwiedzia Cave origin is rather poorly constrained, with only scarce constraints on speleothems formation dating back the onset of this process to late Middle Pleistocene (ca. 300-350 ka; Szczygieł et al. 2021), but not further. Accordingly, the available 
geochronological record provides only a rough approximation for a minimum age for local water table drop and the onset of valley incision. Consequently, Quaternary (Early to Middle Pleistocene) fault activity, that might predate or even coincide with the cave formation cannot be unequivocally excluded. Going back in time to the PrePleistocene, the east marginal fault of the UNKG, one of the most prominent tectonic features in direct vicinity to the Niedźwiedzia Cave, was indisputably activated during the Paleocene-Middle Eocene (Sobczyk et al. 2020). This probably also occurred as part of the thrust regime, as recorded by Stronie Formation rocks overthrust in the Krowiarki Range to the SW on the Cretaceous basin infill (Don 1996). Likewise, western margins of the UNKG were reactivated in thrust regime (Cymerman 1990; Kozdrój 2014), with the proposed Alpine (Neogene) compressional (transpressional) stress field as a triggering factor (Cymerman 1993). For the HPFZ zone reversal tectonic activity is interpreted as a record of an older, major event within the main tectonic fault system, preceding younger, secondary, Late Neogene-Quaternary normal faulting (Stejskal et al. 2006).

The second fault population, $\mathrm{P} 1$, operated under $\sigma 1$ of $\sim 300^{\circ}$, which we interpret as a record of WNW-ESE compression reflecting a latest-Miocene (Adamovič and Coubal 1999; Cloetingh et al. 2005; Nemčok et al. 2007) or, more likely, recent (since the Middle Pleistocene) state of stress for the Bohemian Massif (Reicherter et al. 2008), explained as a manifestation of an active convergence between the Bohemian Massif and Western Carpathians (Jarosiński 2005; Roštínský et al. 2020). For the Sudetes, the distribution of the recent horizontal compression axis (SH) reflects a general $\sim \mathrm{NW}-\mathrm{SE}$ trend (Fig. 1); this scheme could be roughly estimated as having started during the Oligocene-Miocene epochs (Cloetingh et al. 2005). However, borehole breakout measurements reported for the Sudetic Homocline yield two distinct SHmax regimes: NNE-SSW for the external zone and NW-SE for the internal part (Jarosiński 2005), suggesting local divergence of the stress field. In addition, results obtained by in situ measurements in the western part of Upper Silesian Coal Basin-the Carboniferous foreland basin for the Sudetes-indicate NW-SE maximum horizontal compression (Ptáček et al. 2012). Similarly, NW-SE SHmax is also reported by World Stress Map data (Heidbach et al. 2018) for the SW Poland area. Interestingly, results from extensometers from caves and artificial cavities installed i.a. in the Niedźwiedzia Cave in FZ II as well as several other sites in the Sudetes, coincide with the NW-SE regional compression trend (Kontny et al. 2005; Kontny et al. 2010; Stemberk et al. 2010; Stemberk Jr. et al. 2019). However, it must be emphasized that some local variations in stress field distribution for Sudetic Block (eastern sector of SMF) are observed (Pešková et al. 2010) with NNW-SSE compression axis (within an eastern sector of SMF) and NE-SW compression for the Fore-Sudetic Block with recent (Miocene-Quaternary) tectonic activity. Considering the regional data mentioned above, we link the inferred P1 fault population as formed during the last active stress field, thus being younger than P2 (Fig. 6).

\section{Conclusion}

The inversion of fault-slip data collected from the Niedźwiedzia Cave network of the Western Sudetes resolves two major paleostress fields of fault-slip data from 22 faults recognized in marbles into subsets for tectonic stress inversions:

First: wrenching, operating under NE-SW compression, fitting into two main kinematic evolution trends in the Sudetes associated with orogeny: SSW dextral faults and NW- to WNW-striking sinistral faults. We relate this phase to the Upper Nysa Kłodzka Graben inversion and the resulting activity surrounding its faults, including cutting through the Śnieżnik Massif. Kinematic data and fault zone parameters suggest a total displacement along the analyzed faults in the range of tens to over a hundred of meters. NE-SW inferred paleostress regime if interpreted in a regional context, suggests its possible affinity associated with the endCretaceous to Paleogene tectonics through the same mechanism as proposed for Central Europe (Kley and Voigt 2008).

Second: a subset related to WNW-ESE compression produced WS- to WSS-striking dextral faults. We correlate this phase with the youngest and still ongoing (latest Miocene-recent) stress regime induced by ALCAPA tectonic pushes, responsible for recent seismicity in the Central Europe region (Roštínský et al. 2020).

Presented paleostress reconstructions from the Niedźwiedzia Cave combined with available geochronological constraints about tectonic exhumation in the OrlicaŚnieżnik Dome, strongly suggest Alpine intraplate tectonics as a controlling factor for faults evolution in the Śnieżnik Metamorphic Unit. Nevertheless, older pre-Alpine tectonic episodes controls on brittle structure formation and development cannot be unequivocally excluded. 
Fig. 6 Summary of Meso-Cenozoic paleostress field evolution and regional tectonic events for the eastern Orlica-Śnieżnik Dome and Upper Nysa Kłodzka Graben

\begin{tabular}{|l|l|}
\hline Do & $\begin{array}{l}\text { Early Late Cretaceous } \\
\text { NYSA GRABEN FORMATION } \\
\text { OSD E-W extension }\end{array}$ \\
Normal faulting \\
Basin subsidence \\
Regional deep burial
\end{tabular}

Acknowledgements This research was funded by a grant from the Polish National Science Center (DEC-2017/01/X/ST10/00375). We thank the directors of the Niedźwiedzia Cave, especially Artur Sawicki, for the strong support of scientific research in the non-commercial parts of the cave and we thank our caving colleagues, especially Szymon Kostka (SGW Wrocław), for their support during fieldwork. We also thank Lucie Nováková and one anonymous reviewer for helpful and encouraging reviews, Paweł Aleksandrowski and Marcin Dąbrowski for inspiring scientific discussion, Krzysztof Gaidzik for valuable comments, as well as Prof. Wolf-Christian Dullo for careful editorial handling. LiDAR DTM data utilized for this study were used under an academic licence no. DIO.DFT.DSI.7211.1619.2015_PL_N and DIO. DFT.7211.9874.2015_PL_N awarded to the Faculty of Earth Sciences and the Environmental Management University of Wrocław, according to the Polish legal regulations of the administration of Head Office of Land Surveying and Cartography.

Open Access This article is licensed under a Creative Commons Attribution 4.0 International License, which permits use, sharing, adaptation, distribution and reproduction in any medium or format, as long as you give appropriate credit to the original author(s) and the source, provide a link to the Creative Commons licence, and indicate if changes were made. The images or other third party material in this article are included in the article's Creative Commons licence, unless indicated otherwise in a credit line to the material. If material is not included in the article's Creative Commons licence and your intended use is not permitted by statutory regulation or exceeds the permitted use, you will need to obtain permission directly from the copyright holder. To view a copy of this licence, visit http://creativecommons.org/licenses/by/4.0/.

\section{References}

Adamovič J, Coubal M (1999) Intrusive geometries and Cenozoic stress history of the northern part of the Bohemian Massif. Geolines 9:5-14

Aleksandrowski P, Kryza R, Mazur S, Żaba J (1997) Kinematic data on major Variscan strike-slip faults and shear zones in the Polish Sudetes, northeast Bohemian Massif. Geol Mag 133:727-739

Angélier J, Mechler P (1977) Sur une methode graphique de recherché des contraintes principales egalement utilizable en tectonique et en seismologie: la methode des diedres droits. Bull Soc Geol Fr 7(19):1309-1318

Angélier J, Tarantola A, Valette B, Manoussis S (1982) Inversion of field data in fault tectonics to obtain the regional stress- I Single 
phase fault populations: a new method of computing the stress tensor. Geophys J R Astron Soc 69(2):607-621

Awdankiewicz M, Kurowski L, Mastalerz K, Raczyński P (2007) The sudetic marginal fault: a young morphotectonic feature at the NE margin of the Bohemian Massif, Central Europe. Acta Geodyn Geomater 4(4):7-29

Badura J, Rauch M (2014) Tectonics of the Upper Nysa Kłodzka Graben, the Sudetes. Geologia Sudetica 42:137-148

Badura J, Zuchiewicz W, Štìpanèíková P, Przybylski B, Kontny B, Cacoñ S (2007)The Sudetic Marginal Fault: a young morphotectonic feature at the NE margin of the Bohemian Massif, Central Europe. Acta Geodyn Geomater 4(4):7-29

Baroň I, Plan L, Sokol L, Grasemann B, Melichar R, Mitrovica I, Stemberk J (2019) Present-day kinematic behaviour of active faults in the Eastern Alps. Tectonophysics 752:1-23

Brodsky EE, Gilchrist JJ, Sagy A, Collettini C (2011) Faults smooth gradually as a function of slip. Earth Planet Sci Lett 302(1-2):185-193

Brun J-P, Nalpas T (1996) Graben inversion in nature and experiments. Tectonics 15(2):677-687

Chopin F, Schulmann K, Skrzypek E, Lehmann J, Dujardin JR, Martelat JE, Lexa O, Corsini M, Edel JB, Štipska P, Pitra P (2012) Crustal influx, indentation, ductile thinning and gravity redistribution in a continental wedge: building a Moldanubian mantled gneiss dome with underthrust Saxothuringian material (European Variscan belt). Tectonics. https://doi.org/10.1029/2011T C002951

Cloetingh S, Ziegler PA, Beekman F, Andriessen PAM, Matenco L, Bada G, Garcia-Castellanos D, Hardebol N, Dèzes P, Sokoutis D (2005) Lithospheric memory, state of stress and rheology: neotectonic controls on Europe's intraplate continental topography. Quat Sci Rev 24:241-304

Coubal M, Málek J, Adamovič J, Štěpančíková P (2015) Late Cretaceous and Cenozoic dynamics of the Bohemian Massif inferred from the paleostress history of the Lusatian Fault Belt. J Geodyn $87: 26-49$

Cymerman Z (1990) Młodoalpejskie nasunięcie Zieleńca w Górach Orlickich (Sudety). Przegląd Geol 38(10):422-428 (in Polish with Eng summary)

Cymerman Z (1993) Alpejska transpresja w Sudetach. Przegląd Geologiczny 47(10):942-945 (in Polish with Eng summary)

Cymerman Z (1995) Mapy strukturalne Dolnego Śląska w skali 1:50 000. Archiwum Państwowego Instytutu Geologicznego, Wrocław (in Polish)

Cymerman Z (1997) Structure, kinematics and an evolution of the Orlica-Śnieżnik Dome, Sudetes. Prace Państwowego Instytutu Geologicznego 156:120

Delvaux D (1993) The TENSOR program for paleostress reconstruction: examples from the east African and the Baikal rift zones. EUG VII Strasbourg, France, 4-8 April 1993. Abstract supplement $\mathrm{N}^{\circ} 1$ to Terra Nova, vol 5. p 216

Delvaux D, Sperner B (2003) New aspects of tectonic stress inversion with reference to the TENSOR program. Geol Soc Lond 212:75100. https://doi.org/10.1144/GSL.SP.2003.212.01.06

Delvaux D, Moeys R, Stapel G, Petit C, Levi K, Miroshnichenko A, Ruzhich V, San'kov V (1997) Paleostress reconstructions and geodynamics of the Baikal region, Central Asia, Part 2. Cenozoic rifting. Tectonophysics 282:1-38. https://doi.org/10.1016/S0040 -1951(97)00210-2

Don J (1964) Góry Złote i Krowiarki jako elementy składowe metamorfiku Śnieżnika. Geol Sudet 1:70-117 (in Polish with Eng summary)

Don J (1989) Jaskinia na tle ewolucji geologicznej Masywu Śnieżnika. In: Jahn A, Kozłowski S, Wiszniowska T (eds) Jaskinia
Niedźwiedzia w Kletnie. Badania i udostępnianie, Ossolineum, Wrocław, pp 58-79 (in Polish with Eng abstract)

Don J (1996) The Late Cretaceous Nysa Graben: implications for Mesozoic-Cenozoic fault-block tectonics of the Sudetes. Zeitschrift für Geologische Wissenschaften 24:317-324

Don B, Don J (1960) Geneza rowu Nysy na tle badań wykonanych w okolicach Idzikowa. Acta Geol Pol 10(1):71-106 (in Polish with Eng summary)

Don J, Gotowała R (2008) Tectonic evolution of the late Cretaceous Nysa Kłodzka Graben, Sudetes, SW Poland. Geol Sudet 40:51-63

Don J, Opletal M (1997) Budowa i ewolucja geologiczna Masywu Śnieżnika. In: Jahn A, Kozłowski S (eds) Masyw Śnieżnika—zmiany w środowisku przyrodniczym, Polska Agencja Ekologiczna SA, Warszawa, pp 13-26 (in Polish)

Don J, Skácel J, Gotowała R (2003) Geological map of the Śnieżnik Metamorphic Unit, Staré Město Zone and Velké Vrbno Dome. 1:50 000. University of Wrocław (Print)

Dumicz M (1964) Budowa geologiczna krystaliniku Gór Bystrzyckich. Geol Sudet 1:169-208 (in Polish with Eng summary)

Dyjor S (1975) Młodotrzeciorzędowe ruchy tektoniczne w Sudetach i na bloku przedsudeckim. In: Kowalski WC (ed) Współczesne i neotektoniczne ruchy skorupy ziemskiej w Polsce. Wyd. Geol., Warszawa, pp 121-132 (in Polish with Eng summary)

Faulkner DR, Jackson CAL, Lunn RJ et al (2010) A review of recent developments concerning the structure, mechanics and fluid flow properties of fault zones. J Struct Geol 32:1557-1575. https://doi. org/10.1016/j.jsg.2010.06.009

Gunia T (1997) Problem wieku marmurów okolicy Stronia Śląskiego na podstawie mikroskamieniałości (Sudety). Acta Universitatis Wratislaviensis 62:5-48 (in Polish with Eng summary)

Heidbach O, Rajabi M, Cui X, Fuchs K, Müller B, Reinecker J, Reiter K, Tingay M, Wenzel F, Xie F, Ziegler MO, Zoback M-L, Zoback M (2018) The World Stress Map database release 2016: crustal stress pattern across scales. Tectonophysics 744:484-498. https ://doi.org/10.1016/j.tecto.2018.07.007

Jarosiński M (2005) Ongoing tectonic reactivation of the Outer Carpathians and its impact on the foreland: results of borehole breakout measurements in Poland. Tectonophysics 410:189-216. https ://doi.org/10.1016/j.tecto.2004.12.040

Jastrzębski M (2008) Ewolucja tektonometamorficzna marmurów i otaczających łupków łyszczykowych formacji strońskiej (Sudety). Geologos 14(1):51-71 (in Polish with Eng summary)

Jastrzębski M, Żelaźniewicz A, Nowak I, Murtezi M, Larionov A (2010) Protolith age and provenance of metasedimentary rocks in Variscan allochthon units: U-Pb SHRIMP zircon data from the Orlica-Śnieżnik Dome. West Sudetes Geological Magazine 147(3):416-433

Jerzykiewicz T (1968) Remarks on the origin and orientation of joints in the Upper Cretaceous rocks of the Intrasudetic Basin. Geologia Sudetica 4:465-478

Kasza L (1964) Budowa geologiczna górnego dorzecza Białej Lądeckiej. Geol Sudet 1:119-161 (in Polish with Eng summary)

Kim YS, Sanderson DJ (2005) The relationship between displacement and length of faults: a review. Earth Sci Rev 68(3-4):317-334

Kim YS, Peacock DCP, Sanderson DJ (2004) Fault damage zones. J Struct Geol 26:503-517

Kley J (2018) Timing and spatial patterns of Cretaceous and Cenozoic inversion in the Southern Permian Basin. In: Mesozoic Resource Potential in the Southern Permian Basin (B. Kilhams, P. A. Kukla, S. Mazur, T. McKie, H.F. Mijnlieff and K. Van Ojik, eds), Geological Society, London. https://doi.org/10.1144/SP469.12

Kley J, Voigt T (2008) Late Cretaceous intraplate thrusting in central Europe: effect of Africa-Iberia-Europe convergence, not Alpine collision. Geology 36:839-842 
Kontny B, Cacoń S, Košták B, Stemberk J (2005) Methodic analysis of data obtained by monitoring micro-tectonic movements with TM-71 crack gauges in the Polish Sudeten. Acta Geodyn Geomater 2:49-56

Kostka S (2014) Map of the Niedźwiedzia Cave. Central Geological Database. Polish Geological Survey. http://jaskiniepolski.pgi.gov. pl/ Accessed 5 Nov 2019

Koszela S (1997) Petrogeneza marmurów z południowo-wschodniej części metamorfiku Śnieżnika. Geol Sudet 30:58-115 (in Polish with Eng summary)

Kowalski A (2017) Fault geometry and evidence of depocentre migration within a transtensional intra-basinal high-a case study from the Łączna Anticline (Intrasudetic Synclinorium, SW Poland). Geol Quart 61:779-794

Kowalski A (2020) Multistage structural evolution of the end-Cretaceous-Cenozoic Wleń Graben (the Sudetes, NE Bohemian Massif) - a contribution to the post-Variscan tectonic history of SW Poland. Ann Soc Geol Pol. https://doi.org/10.1424/ asgp. 2020.21

Kozdrój W (2014) Results of shallow scientific drillings in the Upper Nysa Kłodzka Graben and the Zieleniec area, Sudetes. Geol Sudet 42:149-159

Mąkolski K, Cacoń S, Jamroz O, Košlák B, Kaczałek M (2008) Investigations regarding Bear Cave massif (Lower Silesia) long-term stability. Acta Carsol 37:279-290

Mazur S, Aleksandrowski P (2001) The Teplá(?) / Saxothuringian suture in the Karkonosze-Izera massif, Western Sudetes, Central European Variscides. Int J Earth Sci 90:341-360

Mazur S, Aleksandrowski P, Szczepański J (2005) The presumed Teplá-Barrandian / Moldanubian terrane boundary in the Orlica Mountains (Sudetes, Bohemian massif): structural and petrological characteristics. Lithos 82(1-2):85-112

Mazur S, Aleksandrowski P, Kryza R, Oberc-Dziedzic T (2010) The Variscan Orogen in Poland. Geol Quart 50(1):89-118

Mazur S, Szczepański J, Turniak K, McNaughton NJ (2012) Location of the Rheic suture in the eastern Bohemian Massif: evidence from detrital zircon data. Terra Nova 24:199-206

Mitchell TM, Faulkner DR (2009) The nature and origin of off-fault damage surrounding strike-slip fault zones with a wide range of displacements: a field study from the Atacama fault system, northern Chile. J Struct Geol 31(8):802-816

Nemčok M, Dilov T, Wojtaszek M, Ludhová L, Klecker RA, Sercombe WJ, Coward MP (2007) Dynamics of the Polish and Eastern Slovakian parts of the Carpathian accretionary wedge: insights from palaeostress analyses. Geol Soc Lond 272:271-302. https://doi. org/10.1144/GSL.SP.2007.272.01.15

Nováková L (2014) Evolution of paleostress fields and brittle deformation in Hronov-Poříčí Fault Zone, Bohemian Massif. Stud Geophys Geod 58:269-288

Nováková L (2015) Tectonic phase separation applied to the Sudetic Marginal Fault Zone (NE part of the Czech Republic). J Mt Sci 12(2):251-267

Nováková L (2016) Paleostress analysis of the tectonic movements of the Sudetic Marginal Fault. Geosci Res Rep 49:177-181

Oberc J (1972) Sudety i Obszary Przyległe, Budowa Geologiczna Polski, vol. 4. Tektonika, Part 2, Wyd. Geol., Warsaw (in Polish)

Pešková I, Hókl J, Štěpančíková P, Stemberk J, Vojtko R (2010) Results of stress analysis inferred from fault slip data along the Sudetic Marginal Fault (NE part of Bohemian Massif). Acta Geol Slovaca 2(1):11-16

Power WL, Tullis TE, Weeks JD (1988) Roughness and wear during brittle faulting. J Geophys Res Solid Earth 93(B12):15268-15278

Ptáček J, Grygar R, Koníček P, Waclawik P (2012) The impact of Outer Western Carpathian nappe tectonics on the recent stressstrain state in the Upper Silesian Coal Basin ( Moravosilesian
Zone, Bohemian Massif ). Geol Carpathica 63:3-11. https://doi. org/10.2478/v10096-012-0002-x

Ramsay JG, Lisle R (2000) Techniques of modern structural geology. Applications of continuum mechanics in structural geology, vol 3. Academic Press, London, pp 1-360

Reicherter K, Froitzheim N, Jarosiński M, Badura J, Franzke H-J, Hansen M, Hübscher H, Müller R, Poprawa P, Reinecker J, Stackebrandt W, Voigt T, Von Eynetten H, Zuchiewicz W (2008) Alpine tectonics north of the Alps. In: McCann (ed) The geology of Central Europe: Mesozoic and Cenozoic, vol 2. Geological Society, London

Roštínský P, Pospíšil L, Švábenský O, Kašing M, Nováková E (2020) Risk faults in stable crust of the eastern Bohemian Massif identified by integrating GNSS, levelling, geological, geomorphological and geophysical data. Tectonophysics 785:228427. https://doi. org/10.1016/j.tecto.2020.228427

Sagy A, Brodsky EE, Axen GJ (2007) Evolution of fault-surface roughness with slip. Geology 35:283-286. https://doi.org/10.1130/ G23235A.1

Sippel J, Scheck-Wenderoth M, Reicherter K, Mazur S (2009) Paleostress states at the south-western margin of the Central European Basin System -Application of fault-slip analysis to unravel a polyphase deformation pattern. Tectonophysics 470:129-146

Sobczyk A, Danišik M, Aleksandrowski P, Anczkiewicz A (2015) Post-Variscan cooling history of the central Western Sudetes (NE Bohemian Massif, Poland) constrained by apatite fission-track and zircon (U-Th)/He thermochronology. Tectonophysics 649:47-57. https://doi.org/10.1016/j.tecto.2015.02.021

Sobczyk A, Kasprzak M, Stefaniak K, Marciszak A (2016) Karst phenomena in metamorphic rocks of the Śnieżnik Massif (East Sudetes): state-of-the-art and significance for tracing a Late-Cenozoic evolution of the Sudetes. Przegląd Geologiczny 64(9):710 718 (in Polish with Eng summary)

Sobczyk A, Sobel E, Georgieva V (2020) Meso-Cenozoic cooling and exhumation history of the Orlica-Śnieżnik Dome (Sudetes, NE Bohemian Massif, Central Europe): insights from apatite fissiontrack thermochronometry. Terra Nova 32:122-133. https://doi. org/10.1111/ter.12449

Solecki A (1994) Tectonics of the North Sudetic Synclinorium. Acta Universitatis Wratislaviensis, 1618, Prace Geol Mineralogiczne 65:1-38

Stejskal V, Štěpančíková P, Vilímek V (2006) Selected geomorphological methods assessing neotectonic evolution of the seismoactive Hronov-Poříčí Fault Zone. Geomorph Slovaca 6:1422

Špaček P, Sýkorová Z, Pazdírková J, Švancara J, Haviŕ J (2006) Present-day seismicity of the south-eastern Elbe Fault System (NE Bohemian Massif). Stud Geophys Geod 50:233-258. https://doi. org/10.1007/s11200-006-0014-Z

Špaček P, Bábek O, Štěpančiková P, Švancara J, Pazdírková J, Sedláček J (2015) The Nysa-Morava Zone: an active tectonic domain with Late Cenozoic sedimentary grabens in the Western Carpathians' foreland (NE Bohemian Massif). Int J Earth Sci 104:963-990

Stemberk J, Košt'ák B, Cacoń S (2010) A tectonic pressure pulse and increased geodynamic activity recorded from the long-term monitoring of faults in Europe. Tectonophysics 487:1-12. https://doi. org/10.1016/j.tecto.2010.03.001

Stemberk J, Coubal M, Stemberk J, Štěpančíková P (2019) Stress analysis of fault slip data recorded within Dědičná Štola gallery in the Rychlebské Hory Mts., NE part of the Bohemian Massif. Acta Geodyn Geomater 16(3):315-330

Szczygieł J (2015a) Cave development in an uplifting fold-and-thrust belt of the Tatra Mountains, Poland. Int J Speleol 44:341-359

Szczygieł J (2015b) Quaternary faulting in the Tatra Mountains, evidence from cave morphology and fault-slip analysis. Geol Carpath 66:245-254. https://doi.org/10.1515/geoca-2015-0023 
Szczygieł J, Gaidzik K, Kicinska D (2015) Tectonic control of cave development: a case study of the Bystra Valley in the Tatra Mts. Poland Ann Soc Geol Pol 85:387-404. https://doi.org/10.14241 /asgp.2015.015

Szczygieł J, Golicz M, Hercman H, Lynch E (2018) Geological constraints on cave development in the plateau-gorge karst of South China (Wulong, Chongqing). Geomorphology 304:50-63. https ://doi.org/10.1016/j.geomorph.2017.12.033

Szczygieł J, Sobczyk A, Hercman H, Mendecki MJ, Gąsiorowski M (2021) Damaged speleothems and collapsed karst chambers indicate paleoseismicity of the NE Bohemian Massif (Niedźwiedzia Cave, Poland). Tectonics. https://doi.org/10.1029/2020TC006459
Torabi A, Berg SS (2011) Scaling of fault attributes: a review. Mar Pet Geol 28(8):1444-1460

Triantafyllou A, Watlet A, Le MS, Camelbeeck T, Civet F, Kaufmann O, Quinif Y, Vandycke S (2019) 3-D digital outcrop model for analysis of brittle deformation and lithological mapping (Lorette cave, Belgium). J Struct Geol 120:55-66. https://doi. org/10.1016/j.jsg.2019.01.001

Uličný D, Laurin J, Čech S (2009) Controls on clastic sequence geometries in a shallow-marine, transtensional basin: the Bohemian Cretaceous Basin, Czech Republic. Sedimentology 56:1077-1114 